\title{
Organic acids alleviate iron chlorosis in chickpea grown on two p-fertilized soils
}

\author{
A. R. Sánchez-Rodríguez ${ }^{1 *}$, M. C. del Campillo ${ }^{1}$, J.Torrent $^{1}$, and D. L. Jones ${ }^{2}$ \\ ${ }^{1}$ Departamento de Agronomía, Universidad de Córdoba, 14071 Córdoba, Spain. ${ }^{2}$ Environment Centre Wales, Bangor University, \\ Gwynedd, LL572UW, UK. "Corresponding author: 102saroa@uco.es
}

\begin{abstract}
The objectives of this paper are to investigate the response of chickpea growing on two iron $(\mathrm{Fe})$ chlorosisinducing calcareous soils, with different $\mathrm{Fe}$ availability, generously supplied with phosphate $(\mathrm{P})$, and to evaluate the effectiveness of a mixture of organic acids (citric, oxalic and malic) to alleviate Fe chlorosis symptoms. Application of $\mathrm{P}$ (+P treatment) aggravated Fe deficiency irrespective of the soil. Phosphorus-induced Fe chlorosis was alleviated when organic acids were also applied to the soil $(+\mathrm{P}+\mathrm{OA}$ treatment), which was reflected in increased leaf chlorophyll concentration and decreased root ferric reductase activity in the plants growing on both soils; the effect was stronger for plants grown on the soil with the lowest Fe-available content. However, Fe chlorosis was still more severe than in the control ( $-\mathrm{P}$ treatment) plants. The need of $-\mathrm{P}$ treatment plants to explore soil in order to take up nutrients is reflected in their root architecture, reduced root diameter and increased length, surface and volume relative to $+\mathrm{P}$ and $+\mathrm{P}+\mathrm{OA}$ roots. Organic acids alleviate $\mathrm{Fe}$ chlorosis in function of non crystalline $\mathrm{Fe}$ oxides content but inhibit the root response mechanisms as a consequence of increasing Fe concentration in the soil solution.
\end{abstract}

Keywords: Calcareous soils, iron oxides, citrate, malate, oxalate, phosphate fertilization

\section{Introduction}

Calcareous soils cover about the $30 \%$ of world's total land area, with their main properties being their intrinsically high calcium carbonate content and alkalinity ( $\mathrm{pH}$ 7.5-8.5). Typically, the bioavailability of micronutrients (e.g. $\mathrm{Fe}, \mathrm{Mn}, \mathrm{Cu}$, $\mathrm{Zn}$ ) is low in these soils due to their poor solubility at high $\mathrm{pH}$. Consequently, micronutrient deficiency in crop production is a worldwide problem affecting many crops (citrus, olive, grapevine, cereals and berries, among others) grown in calcareous soils.
The main visual symptom of $\mathrm{Fe}$ deficiency is leaf chlorosis (i.e. interveinal yellowing of the youngest leaves), which ultimately leads to leaf necrosis, reduced growth and poor yields. The high content and reactivity of carbonate combined with the low content of poorly crystalline Fe oxides in soil play a key role in Fe deficiency (Díaz et al., 2009). Therefore strategies are needed to enhance Fe dissolution and diffusion in the rhizosphere to enhance plant growth. 
The interactive effect of phosphorus (P) on plant $\mathrm{Fe}$ deficiency remains poorly understood. The high affinity of phosphate for the surface of $\mathrm{Fe}$ oxides and oxyhydroxides (Bigham et al., 2002) reduces $\mathrm{Fe}$ dissolution and bioavailability (Cornell and Schwertmann, 2003). Furthermore, P can interfere with the reduction of $\mathrm{Fe}$ (III) complexed with different organic ligands (Brown and Olsen, 1980), such as organic acids (e.g. citrate) or phytosiderophores (e.g. mugineic acid).

Since the observation of de Kock and Hall (1955) that chlorotic leaves had a higher $\mathrm{P} / \mathrm{Fe}$ ratio than non-chlorotic leaves in some plant species (e.g. Bougainvillea glabra, Sambucusnigra, Ilex aquifolium, Pelargonium zonale and Spiraea japonica), different experiments have suggested that high $\mathrm{P}$ fertilization exerts a negative effect on $\mathrm{Fe}$ nutrition. Examples of this phenomenon exists for a wide range of crop plants including, field-grown soybean and grapevine rootstocks (Marschner and Schropp, 1977) and hydroponically grown corn, oat, soybeans, barley, peanut and tomato (Brown and Olsen, 1980; Ladouceur et al., 2006). This had led some authors to suggest that $\mathrm{P}$ competes physiologically with $\mathrm{Fe}$ in plant tissues.

Sánchez-Rodríguez et al. (2013) showed that high levels of $\mathrm{P}$ aggravated Fe chlorosis in chickpea, peanut, lupin and sorghum grown on artificial substrates prepared with mixtures of $\mathrm{Fe}$ oxide (ferrihydrite)coated, calcium carbonate and quartz sand. The effect was more evident at low concentrations of $\mathrm{Fe}$ oxide in the substrate when the phosphate ion was strongly adsorbed on its surface (Cornel and Schwertmann, 2003) decreasing the solubility of soil Fe.

By contrast, there are also studies rejecting the hypothesis that $\mathrm{P}$ can aggravate Fe chlorosis: Kovanci et al. (1978) in field-grown mandarin, Müllner (1979) and Mengel et al. (1979) in field-grown grapevine, Mengel et al. (1984) in pot-grown grapevine, Romera et al. (1991) in nutrient solution-grown peach rootstocks, Samar et al. (2007) in pot-grown 'Delicious' apple, and Balal et al. (2011) in two pot-grown Prunus rootstocks.
These authors support the idea put forward by Mengel et al. (1984) that the high $\mathrm{P}$ content found in chlorotic leaves was actually the result and not the cause for $\mathrm{Fe}$ chlorosis.

When tissue Fe levels fall below a critical threshold, plants can exploit a range of strategies to enhance the mobilization of $\mathrm{Fe}$ in the rhizosphere including: (1) acidification of the rhizosphere by the excretion of $\mathrm{H}^{+}$, (2) stimulation of the Fe-reducing capacity through a ferric reductase system, (3) exudation of phytosiderophores by Strategy II plants, and (4) root exudation of organic acids and phenolic compounds. Furthermore, morphological changes occur in plants (except in grasses) in response to $\mathrm{Fe}$ deficiency, including inhibition of root elongation, an increase in the diameter of the apical root zones and abundant root hair formation.

Root exudation of organic acid anions (e.g. citrate, malate, oxalate) is thought to represent one of the main strategies used by plants growing on calcareous soils to enhance nutrient mobilization and acquisition under $\mathrm{P}$ and micronutrient limiting conditions (Jones, 1998). After release into the rhizosphere the organic acids can undergo a number of fates including complexation of metals which induces mineral dissolution and enhances the solubility and diffusion of micronutrients towards the root (Ryan et al., 2001). This response is typically enhanced by co-acidification of the soil via the roots $\mathrm{H}^{+}$-ATPase or via release of organic acid anions in a protonated form (Jones, 1998). However, the behaviour of organic acids in soil is complex and a range of processes can occur which can reduce the magnitude of the nutrient mobilization response including: (1) consumption of the organic acids by the soil microbial community, (2) immobilization on anion exchange sites, (3) precipitation (e.g. Ca-oxalate), (4) abiotic mineralization, and (5) leaching down the soil profile (Jones, 1998). While organic acids such as citrate and malate have been shown to induce the dissolution of insoluble ferric oxyhydroxides in soil in the absence of plants, their ability to mobilize $\mathrm{Fe}$ in a complex rhizosphere environment remains largely unknown. 
The aims of the present study were therefore, (1) to investigate the response of chickpea growing on two $\mathrm{Fe}$ chlorosis-inducing calcareous soils, with a different $\mathrm{Fe}$ bioavailability, when the soil was generously supplied with phosphate, and (2) to evaluate the effectiveness of a mixture of organic acids (citric, oxalic and malic) to alleviate $\mathrm{Fe}$ chlorosis symptoms under high-P conditions.

\section{Materials and Methods}

\subsection{Soils}

The experiments used two calcareous soils from southern Spain. The first called "soil poor in acid oxalate extractable $\mathrm{Fe}\left(\mathrm{Fe}_{\mathrm{ox}}\right)$ " was collected from a vineyard in Montilla, Province of Córdoba $\left(37^{\circ} 34^{\prime} 26^{\prime \prime} \mathrm{N}, 4^{\circ} 38^{\prime} 25^{\prime \prime} \mathrm{W}\right)$ whilst the second called "soil rich in $\mathrm{Fe}_{\text {ox }}$ " was collected from an olive orchard in the Province of Jaén (37 $59^{\prime} 41^{\prime \prime} \mathrm{N}, 3^{\circ} 13^{\prime} 37^{\prime}$ 'W). Crops growing on both soils exhibited strong signs of Fe chlorosis.

Organic carbon content (rapid dichromate oxidation) was 15 and $16 \mathrm{~g} \mathrm{~kg}^{-1}$ for soil poor in $\mathrm{Fe}_{\text {ox }}$ and soil rich in $\mathrm{Fe}_{\mathrm{ox}}$, respectively, and clay content (pipette method) was 210 and $300 \mathrm{~g} \mathrm{~kg}^{-1}$ for soil poor in $\mathrm{Fe}_{\mathrm{ox}}$ and soil rich in $\mathrm{Fe}_{\mathrm{ox}}$, respectively. Both soils were highly calcareous: calcium carbonate equivalent (CCE) (determined by weight loss upon treatment with $6 \mathrm{M} \mathrm{HCl}$; van Wesemael, 1955) was $490 \mathrm{~g} \mathrm{~kg}^{-1}$ for soil poor in $\mathrm{Fe}_{\text {ox }}$ and $380 \mathrm{~g} \mathrm{~kg}^{-1}$ for soil rich in $\mathrm{Fe}_{\mathrm{ox}}$, and active calcium carbonate equivalent (ACCE) (Drouineau, 1942) was $70 \mathrm{~g} \mathrm{~kg}^{-1}$ for soil poor in $\mathrm{Fe}_{\text {ox }}$ and $150 \mathrm{~g} \mathrm{~kg}^{-1}$ for soil rich in $\mathrm{Fe}_{\mathrm{ox}}$. The $\mathrm{pH}$ (potentiometric measurement in a relation of 1:2.5 soil in water suspension) was typical of calcareous soils (8.6 for soil poor in $\mathrm{Fe}_{\text {ox }}$ and 8.4 for soil rich in $\mathrm{Fe}_{\mathrm{ox}}$ ), and cation exchange capacity (extraction with $1 \mathrm{M} \mathrm{NH}_{4} \mathrm{OAc}$ buffered at $\mathrm{pH}$ 7) was $8.3 \mathrm{cmol}_{\mathrm{c}} \mathrm{kg}^{-1}$ for soil poor in $\mathrm{Fe}_{\text {ox }}$ and $19.5 \mathrm{cmol}_{\mathrm{c}}$ $\mathrm{kg}^{-1}$ for soil rich in $\mathrm{Fe}_{\mathrm{ox}}$, calcium being the dominant exchangeable cation due to the high carbonate content in both soils. Electrical conductivity of the 1:5 (w/v) soil:water extract was $0.15 \mathrm{dS} \mathrm{m}^{-1}$ in soil poor in $\mathrm{Fe}_{\mathrm{ox}}$ and $0.08 \mathrm{dS} \mathrm{m}^{-1}$ in soil rich in $\mathrm{Fe}_{\text {ox }}$. Olsen $\mathrm{P}$ (extraction with $0.5 \mathrm{M} \mathrm{NaHCO}_{3}$ buffered at $\mathrm{pH} 8.5$; Olsen et al., 1954) was low in both soils $\left(4.1 \mathrm{mg} \mathrm{kg}^{-1}\right.$ in soil poor in $\mathrm{Fe}_{\mathrm{ox}}$ and $2.4 \mathrm{mg} \mathrm{kg}^{-1}$ in soil rich in $\mathrm{Fe}_{\mathrm{ox}}$ ). Citrate/ bicarbonate/dithionite-extractable Fe (Fed; Mehra and Jackson, 1960 , with extraction carried out at $25^{\circ} \mathrm{C}$ for $16 \mathrm{~h}$ ) was $1.80 \mathrm{~g} \mathrm{~kg}^{-1}$ in soil poor in $\mathrm{Fe}_{\text {ox }}$ and $4.40 \mathrm{~g} \mathrm{~kg}^{-1}$ in soil rich in $\mathrm{Fe}_{\mathrm{ox}}$. Citrate/ascorbate -extractable $\mathrm{Fe}$ (Feca; Reyes and Torrent 1997) was $0.64 \mathrm{~g} \mathrm{~kg}^{-1}$ in soil poor in $\mathrm{Fe}_{\text {ox }}$ and $1.21 \mathrm{~g} \mathrm{~kg}^{-1}$ in soil rich in $\mathrm{Fe}_{\mathrm{ox}}$. Acid oxalate extractable $\mathrm{Fe}\left(\mathrm{Fe}_{\mathrm{ox}}\right.$; Schwertmann, 1964) was $0.23 \mathrm{~g} \mathrm{~kg}^{-1}$ in soil poor in $\mathrm{Fe}_{\mathrm{ox}}$ and $0.71 \mathrm{~g} \mathrm{~kg}^{-1}$ in soil rich in $\mathrm{Fe}_{\mathrm{ox}}$, being the main difference between the two soils. Both $\mathrm{Fe}_{\mathrm{ox}}$ and Feca are considered to provide a good estimate of the Fe present in the form of poorly crystalline Fe oxides (Reyes and Torrent, 1997); thus, the availability of $\mathrm{Fe}$ is higher in the soil rich in $\mathrm{Fe}_{0 \times}$ than in soil poor in $\mathrm{Fe}_{\mathrm{ox}}$.

\subsection{Plant growth experiments}

The experimental design included three treatments: a control (no P added to the soil; "-P" treatment) and two treatments where phosphate was applied by spraying the soil homogeneously with a $\mathrm{Ca}\left(\mathrm{H}_{2} \mathrm{PO}_{4}\right)_{2}$ solution at a rate of $100 \mathrm{mg} \mathrm{P} \mathrm{kg}^{-1}$ before transplantation without ("+P" treatment) or with organic acids (" $+\mathrm{P}+\mathrm{OA}$ " treatment, the same $\mathrm{P}$ spraying than $+\mathrm{P}$ ). In the latter treatment, plants were watered with $10 \mathrm{~mL}$ of a solution containing citric, oxalic and malic acids $(10 \mathrm{mM})$ every day from the fifteenth day after transplantation (DAT), when roots were well established in the soil, until harvest. The concentration was chosen to reflect high rates of organic acid exudation (Jones, 1998).

Chickpea (Cicer arietinum L., cv. ICC 11224) was grown in cylindrical plastic pots $7.5 \mathrm{~cm}$ in diameter and $10 \mathrm{~cm}$ high provided with drainage holes at the bottom and filled with $250 \mathrm{~g}$ of soil. Seeds were germinated for $72 \mathrm{~h}$ at $20^{\circ} \mathrm{C}$ and three seedlings were transplanted to each pot, which was placed in a greenhouse with a photoperiod of $16 \mathrm{~h} \mathrm{~d}^{-1}$, a temperature of 20 
${ }^{\circ} \mathrm{C}$ and a relative humidity of $45-55 \%$ for $27 \mathrm{~d}$. A micronutrient-rich, Fe-free, P-poor modified Hoagland nutrient solution was applied according to the needs of each crop. The composition of the nutrient solution was $\mathrm{Ca}\left(\mathrm{NO}_{3}\right)_{2} \bullet 4 \mathrm{H}_{2} \mathrm{O}(5 \mathrm{mM}), \mathrm{KNO}_{3}(5 \mathrm{mM}), \mathrm{MgSO}_{4}$ (2 mM), $\mathrm{KCl}(0.1 \mu \mathrm{M}), \mathrm{H}_{2} \mathrm{KPO}_{4}(0.25 \mathrm{mM}), \mathrm{H}_{3} \mathrm{BO}_{3}$ $(50 \mu \mathrm{M}), \mathrm{MnSO}_{4} \cdot \mathrm{H}_{2} \mathrm{O}(4 \mu \mathrm{M}), \mathrm{ZnSO}_{4} \cdot 7 \mathrm{H}_{2} \mathrm{O}(4 \mu \mathrm{M})$, $\mathrm{CuSO}_{4} \cdot 5 \mathrm{H}_{2} \mathrm{O}(0.1 \mu \mathrm{M}), \mathrm{Na}_{2} \mathrm{MoO}_{4}(6 \mu \mathrm{M})$. The pots were weighed daily and the soil kept at near field capacity with deionized water. Five replicates were used in all treatments and soils.

After the appearance of the first symptoms of $\mathrm{Fe}$ chlorosis at 21 DAT, the leaf chlorophyll concentration was periodically monitored using a SPAD meter (SPAD 502 Portable Chlorophyll Meter, Minolta Camera Co., Osaka, Japan). To validate the SPAD readings, 30 leaves of the younger and completely expanded leaves exhibiting a variable degree of $\mathrm{Fe}$ chlorosis were collected from various plants. After measuring the leaflet fresh weight and SPAD, chlorophyll was extracted with 96 wt.\% ethanol. Because SPAD and leaf chlorophyll concentration per unit surface were highly correlated $(r=0.81, p<0.001)$ the SPAD value was adopted as a reliable proxy for chlorophyll concentration.

During the growth period, plant height and number of leaves were measured periodically. Soil solution was extracted from each pot 20 DAT and the day before harvest using Rhizon ${ }^{\circledR}$ samplers (Rhizosphere Research Products, Wageningen, Netherlands) and analysed for $\mathrm{Fe}$ and $\mathrm{P}$. At harvest, the plants were removed from the moist soil carefully and the soil adhering to the roots (about $30 \mathrm{~g}$ per pot) was collected and stored at $4{ }^{\circ} \mathrm{C}$. The plant was then taken to the laboratory and its roots were washed and soaked for 30 min in plastic vessels with $50 \mathrm{~mL}$ of a nutrient solution analogous to the one described previously except that it contained no micronutrients and adjusted to $\mathrm{pH} 5.0$ with $\mathrm{KOH}(10 \mathrm{mM})$. To determine their ferric reductase activity, the plant roots were submerged for $1 \mathrm{~h}$ in $40 \mathrm{~mL}$ of a reduction assay solution without micronutrients that contained $100 \mu \mathrm{M}$ Fe (III)-EDTA,
$300 \mu \mathrm{M}$ Ferrozine and $5 \mathrm{mM}$ Mes buffer adjusted to pH 5.0 with $\mathrm{KOH}$. The amount of Fe (II)-ferrozine was determined spectrophotometrically at $562 \mathrm{~nm}$ using an extinction coefficient of $29800 \mathrm{M}^{-1} \mathrm{~cm}^{-1}$. Subsequently, the roots were washed with deionized water, scanned and their length determined using WinRHIZO ${ }^{\circledR}$ (Regent Instruments Inc., Canada). $\mathrm{N}_{2}$-fixing nodules were then separated from the roots by hand. Root, shoot and nodule dry weight were determined after oven drying $\left(80^{\circ} \mathrm{C}, 72\right.$ h) and mineral element concentrations in aerial parts and roots were determined after dry-ashing and digestion with hydrochloric acid (Adrian, 1973). Magnesium, Fe and $\mathrm{Mn}$ in solution were determined using a Varian 720 ES ICP-OES, $\mathrm{K}$ and $\mathrm{Ca}$ by flame emission and $\mathrm{P}$ by the molybdenum blue method of Murphy and Riley (1962). The $\mathrm{N}$ and $\mathrm{C}$ concentration was determined by direct combustion of the plant material using a TruSpec ${ }^{\circledR}$ analyser (Leco Corp., St Joseph, MI, USA).

\section{3. ${ }^{14} \mathrm{C}$ organic acid mineralization}

To determinate the rate of microbial organic acid degradation, ${ }^{14} \mathrm{C}$-labelled citrate, oxalate and malate, were added to soil and the rate of ${ }^{14} \mathrm{CO}_{2}$ evolution determined over a $72 \mathrm{~h}$ period. Briefly, $200 \mu \mathrm{L}$ of an organic acid solution $(10 \mathrm{mM})$ containing citrate, oxalate and malate (of which only one was ${ }^{14} \mathrm{C}$-labeled) was placed in $60 \mathrm{~mL}$ polypropylene tubes containing $5.0 \mathrm{~g}$ of field-moist rhizosphere soil obtained from the harvested pots. The specific activity of citrate was $0.20 \mathrm{kBq} \mathrm{mL}^{-1}$, $0.44 \mathrm{kBq} \mathrm{mL}^{-1}$ for oxalate and $0.45 \mathrm{kBq} \mathrm{mL}^{-1}$ for malate. After organic acid addition, a $1 \mathrm{M} \mathrm{NaOH}$ trap $(1 \mathrm{~mL})$ was placed on top of the soil and the tubes sealed and incubated in the dark at $20{ }^{\circ} \mathrm{C}$. The $\mathrm{NaOH}$ traps were removed at 1, 2, 4, 8, 10, 24, 32, 48 and $72 \mathrm{~h}$ after organic acid addition and their ${ }^{14} \mathrm{CO}_{2}$ content determined by liquid scintillation counting. Five replicates of each treatment (the same number of pots) were performed.

\subsection{Statistical analyses}

Statistical analyses were performed using STATISTIX 9.0 software (Analytical Software, Tallahassee, FL, USA). The analysis of variance (ANOVA) was 
based on a completely randomized design with three treatments $(-\mathrm{P},+\mathrm{P}$ and $+\mathrm{P}+\mathrm{OA})$ in each soil. Means were separated using the Least Significant Difference (LSD) test at a probability level of 0.05 . Unless otherwise indicated the term "significant" refers to this probability level.
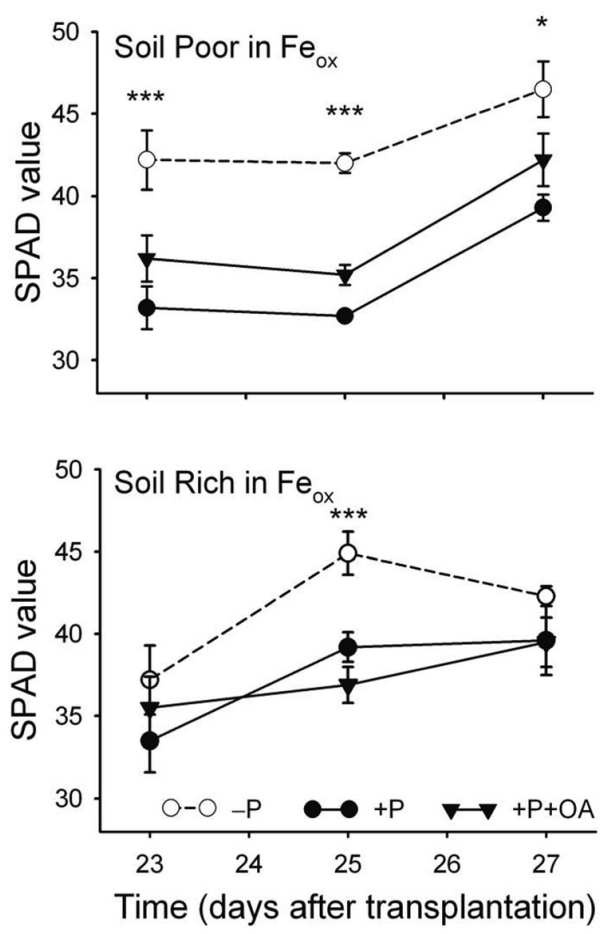

Figure 1. Influence of soil $\mathrm{P}(+\mathrm{P})$ and $\mathrm{P}+$ organic acid $(+\mathrm{P}+\mathrm{OA})$ addition on the chlorophyll content (SPAD value) of chickpea leaves grown in two calcareous soils (soil poor in $\mathrm{Fe}_{\text {ox }}$ and soil rich in $\mathrm{Fe}_{\mathrm{ox}}$ ). Values represent mean \pm standard error $(\mathrm{n}=5) . \mathrm{Fe}_{\mathrm{ox}}$ : Acid oxalate extractable $\mathrm{Fe} .{ }^{*}$ indicates $p<0.05$ and $* * *$ indicates $p<0.001$.

\section{Results and Discussion}

3.1. SPAD values, chlorophyll content and ferric reductase activity

Figure 1 shows the time course of the SPAD value for the youngest leaves of chickpea as a function of soil and treatment. Iron deficiency symptoms (leaf chlorosis) appeared at the end of the third week after transplantation. Generally, both $\mathrm{P}$ fertilization and organic acid addition to the soil $(+\mathrm{P}$ and $+\mathrm{P}+\mathrm{OA}$ treatments) resulted in reduced SPAD readings in the plants grown on both soils. The SPAD value of the control plants (-P) was significantly higher than the rest of the treatments at all measurement times for the soil poor in $\mathrm{Fe}_{o x}(p<0.001$ at 23 and $25 \mathrm{DAT}$, and $p<0.05$ at $27 \mathrm{DAT})$ and at $25 \mathrm{DAT}(p<0.001)$ for the soil rich in $\mathrm{Fe}_{o x}$. Relative to the $+\mathrm{P}$ treatment, the $+\mathrm{P}+\mathrm{OA}$ treatment resulted in higher SPAD readings for the plants grown on the soil poor in $\mathrm{Fe}_{\mathrm{ox}}$; this effect, however, was not observed for the soil with a higher content in $\mathrm{Fe}_{\mathrm{ox}}$. Similar results were obtained for direct measurements of chlorophyll content in the last leaflet and two last leaflets (Table 1). The key role played by the poorly crystalline Fe oxides in supplying Fe to the plant (Díaz et al., 2009) was probably responsible for the higher chlorophyll content in plants grown on the soil rich in $\mathrm{Fe}_{\text {ox }}$ (Table 1 and Figure 1), however, no significant differences were found in SPAD values between soils.

The ferric reductase activity of plant roots was significantly higher in plants grown on soils supplied with $\mathrm{P}(+\mathrm{P}$ and $+\mathrm{P}+\mathrm{OA}$ treatments $)$ than in the control treatment $(-\mathrm{P})$ (Table 1). Furthermore, the ferric reductase activity of plants treated with $\mathrm{P}$ and organic acids $(+\mathrm{P}+\mathrm{OA}$ treatment) was lower than those treated only with $\mathrm{P}(+\mathrm{P}$ treatments) (Table 1). The chlorophyll content was negatively correlated with the ferric reductase activity $(r=-0.65, \mathrm{p}=0.016$, for plants grown on the soil poor in $\mathrm{Fe}_{\mathrm{ox}}$; and $r=-0.60, p=$ 0.027 , for plants grown on the soil rich in $\mathrm{Fe}_{\text {ox }}$ ), as a result of the Fe-stress reaction. This correlation was reported previously for other crops, (Romera et al., 1991; Ellsworth et al., 1997). 
Table 1. Chlorophyll concentration in the last leaflet (1) and the two last leaflets (1-2), root ferric reductase activity, dry weight (DW), last leaflet weight and root nodule weight in chickpea in response to the addition of $\mathrm{P}(+\mathrm{P})$ and $\mathrm{P}$ plus organic acids $(+\mathrm{P}+\mathrm{OA})$ to soil poor in $\mathrm{Fe}_{\text {ox }}$ and soil rich in $\mathrm{Fe}_{\text {ox }}$. Values represent mean \pm standard error $(n=5)$. Letters $a$ and $b$ denote significant differences between treatments at the $p<0.05$ level. $\mathrm{Fe}_{\mathrm{ox}}$ : Acid oxalate extractable Fe.

\begin{tabular}{|c|c|c|c|c|c|c|}
\hline Treatment & $\begin{array}{l}\text { Chlorophyll } 1 \\
\mathrm{mg} \mathrm{g}^{-1}\end{array}$ & Chorophyll 1-2 & $\begin{array}{l}\text { Ferric reductase } \\
\mathrm{nmol} \mathrm{g}^{-1} \mathrm{~h}^{-1}\end{array}$ & $\begin{array}{l}\text { DW } \\
\text { g plant }^{-1}\end{array}$ & $\begin{array}{l}\text { Leaflet weight } \\
\text { mg plant }^{-1}\end{array}$ & Nodules \\
\hline & \multicolumn{6}{|c|}{ Soil Poor in Feox } \\
\hline$-\mathrm{P}$ & $4.9 \pm 0.4 \mathrm{a}$ & $4.5 \pm 0.2 \mathrm{a}$ & $263 \pm 25 b$ & $0.29 \pm 0.02 \mathrm{a}$ & $3.9 \pm 0.1$ & $3.4 \pm 0.5 b$ \\
\hline$+\mathrm{P}$ & $3.5 \pm 0.2 \mathrm{~b}$ & $3.4 \pm 0.2 \mathrm{~b}$ & $430 \pm 36 a$ & $0.31 \pm 0.01 \mathrm{a}$ & $4.9 \pm 0.5$ & $17.1 \pm 2.3 \mathrm{a}$ \\
\hline$+\mathrm{P}+\mathrm{OA}$ & $4.3 \pm 0.3 \mathrm{ab}$ & $4.1 \pm 0.2 \mathrm{a}$ & $378 \pm 46 \mathrm{ab}$ & $0.23 \pm 0.02 \mathrm{~b}$ & $3.7 \pm 0.3$ & $13.7 \pm 2.5 \mathrm{a}$ \\
\hline \multirow[t]{2}{*}{$P$-value } & 0.019 & 0.007 & 0.035 & 0.003 & 0.051 & 0.001 \\
\hline & \multicolumn{6}{|c|}{ Soil Rich in Feox } \\
\hline$-\mathrm{P}$ & $6.4 \pm 0.2$ & $7.1 \pm 0.6$ & $301 \pm 62 b$ & $0.25 \pm 0.01$ & $2.8 \pm 0.2$ & $6.0 \pm 0.7 \mathrm{~b}$ \\
\hline$+\mathrm{P}$ & $5.6 \pm 0.4$ & $6.4 \pm 0.7$ & $1023 \pm 227 \mathrm{a}$ & $0.29 \pm 0.01$ & $3.3 \pm 0.4$ & $14.8 \pm 2.2 \mathrm{a}$ \\
\hline$+\mathrm{P}+\mathrm{OA}$ & $6.2 \pm 0.1$ & $5.8 \pm 0.1$ & $784 \pm 91 \mathrm{a}$ & $0.24 \pm 0.03$ & $2.5 \pm 0.1$ & $18.5 \pm 2.4 \mathrm{a}$ \\
\hline$P$-value & 0.656 & 0.324 & 0.019 & 0.093 & 0.150 & 0.002 \\
\hline
\end{tabular}

\subsection{Plant growth}

Vigorous plant growth was observed on both soils. Plants grew slightly taller on soil poor in $\mathrm{Fe}_{\mathrm{ox}}$ than on soil rich in $\mathrm{Fe}_{\text {ox }}$ (Figure 2), which was not unexpected because of the significantly different physical and chemical properties of the two soils. Significant differences in plant height were found at harvest, with plants grown under the $+\mathrm{P}$ treatment being significantly taller that the other two treatments. Dry weight (DW) and leaflet weight at harvest were lower in the $+\mathrm{P}+\mathrm{OA}$ treatment than in the $-\mathrm{P}$ and $+\mathrm{P}$ plants, but differences were significant only for the soil poor in $\mathrm{Fe}_{\text {ox }}$ (Table 1). Nodule weight was significantly greater in the $+\mathrm{P}$ and $+\mathrm{P}+\mathrm{OA}$ treatments than in the -P plants (Table 1), as expected from the known favorable effect of $\mathrm{P}$ on nodulation (Cassman et al., 1980).

Vigorous plant growth was observed on both soils. Plants grew slightly taller on soil poor in $\mathrm{Fe}_{\text {ox }}$ than on soil rich in $\mathrm{Fe}_{\mathrm{ox}}$ (Figure 2), which was not unexpected because of the significantly different physical and chemical properties of the two soils. Significant differences in plant height were found at harvest, with plants grown under the $+\mathrm{P}$ treatment being significantly taller that the other two treatments. Dry weight (DW) and leaflet weight at harvest were lower in the $+\mathrm{P}+\mathrm{OA}$ treatment than in the $-\mathrm{P}$ and $+\mathrm{P}$ plants, but differences were significant only for the soil poor in $\mathrm{Fe}_{\text {ox }}$ (Table 1). Nodule weight was significantly greater in the $+P$ and $+\mathrm{P}+\mathrm{OA}$ treatments than in the $-\mathrm{P}$ plants (Table 1), as expected from the known favorable effect of $\mathrm{P}$ on nodulation (Cassman et al., 1980).

Properties of root architecture as a function of soil type and amendment are shown in Table 2. Root diameter increased in the order $-\mathrm{P}<+\mathrm{P}<+\mathrm{P}+\mathrm{OA}$ plants but differences were significant only between $-\mathrm{P}$ and $+\mathrm{P}+\mathrm{OA}$ plants grown on the soil rich in $\mathrm{Fe}_{\text {ox }}$. Root length, surface area and volume, and number of tips decreased in the order $-\mathrm{P}>+\mathrm{P}>+\mathrm{P}+\mathrm{OA}$ plants, most of the significant differences being found in the root of plants grown on the soil poor in $\mathrm{Fe}_{\text {ox }}$ (Table 2). 

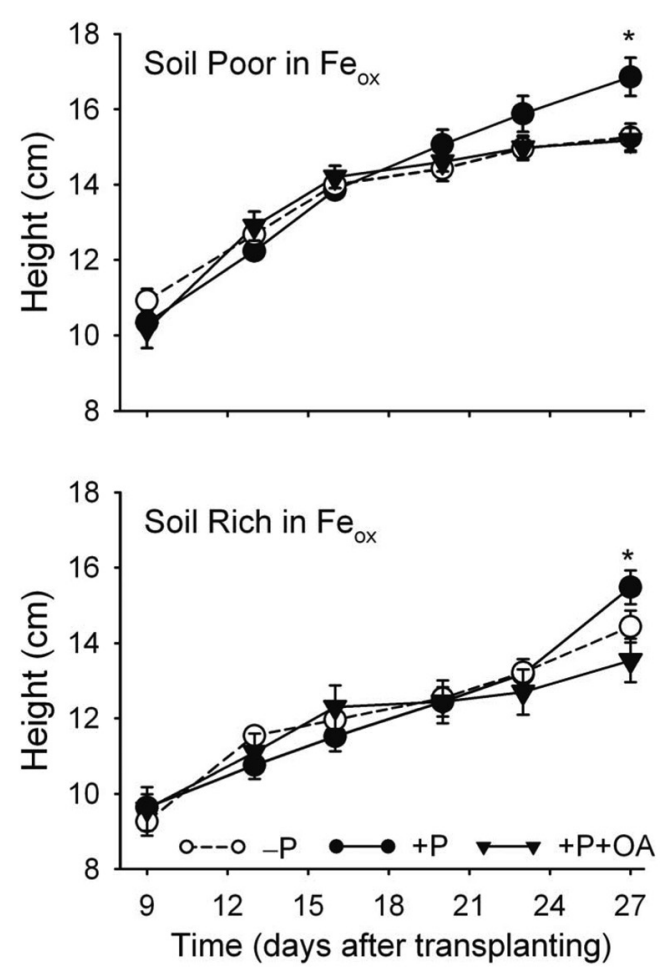

Figure 2. Influence of soil $\mathrm{P}(+\mathrm{P})$ and $\mathrm{P}+$ organic acid $(+\mathrm{P}+\mathrm{OA})$ addition on the height of chickpea plants grown in two calcareous soils (soil poor in $\mathrm{Fe}_{\text {ox }}$ and soil rich in $\mathrm{Fe}_{\mathrm{ox}}$ ). Values represent mean \pm standard error $(\mathrm{n}=5) . \mathrm{Fe}_{\mathrm{ox}}$ : Acid oxalate extractable Fe. * indicates $p<0.05$.

As expected, the concentration of $\mathrm{P}$ in the soil solution was higher for the $+\mathrm{P}$ and $+\mathrm{P}+\mathrm{OA}$ treatments than for the $-\mathrm{P}$ treatment (Table 3). Both the concentration of $\mathrm{Fe}$ and the $\mathrm{pH}$ of the soil solution were significantly higher for the $+\mathrm{P}+\mathrm{OA}$ than for the other two treatments.

Root and root hair production are typically stimulated by low P tissue concentrations. No stimulatory effect on root hair production by Fe deficiency was observed in comparison with other experiments possibly because the effect of a macronutrient like $\mathrm{P}$ in soil solution is more important from a regulatory perspective.
Amendment of the soil with organic acids $(+\mathrm{P}+\mathrm{OA})$ increased the concentration of $\mathrm{Fe}$ in soil solution (Table 3). This would increase the availability of $\mathrm{Fe}$ and may be responsible for reducing $\mathrm{Fe}$ chlorosis symptoms in comparison with the $\mathrm{P}$ treated plants $(+\mathrm{P})$ (see chlorophyll content in the last leaflet, Table $1)$.

\subsection{Organic acid mineralization}

Figure 3 shows the time-dependent mineralization of the mixture of citrate, oxalate and malate for each soil and labeled organic acid. All the ${ }^{14} \mathrm{CO}_{2}$ evolution data fitted well to sigmoidal curves $\left(0.95<r^{2}<0.99, p<\right.$ $0.001)$ Overall, mineralization was faster for citrate than for the other two anions which exhibited similar rates of mineralization. Except for oxalate in the soil poor in $\mathrm{Fe}_{\mathrm{ox}}$, the mineralization rate was higher or similar to in the soils supplied with $\mathrm{P}$ than in the control soils, consistent with the idea that $\mathrm{P}$ promotes soil microbial activity. The low mineralization rate of oxalate in soil poor in $\mathrm{Fe}_{\text {ox }}$ not previously supplied with organic acids (treatments $-\mathrm{P}$ and $+\mathrm{P}$ ) agree with previous data on the resistance of oxalate to microbial degradation (Ström et al., 2002) and may have relationship with the rapid precipitation of $\mathrm{Ca}$ oxalate in a calcareous soil not previously supplied with this anion. However, the mineralization patterns of oxalate in soil rich in $\mathrm{Fe}_{\text {ox }}$ differ markedly from those of the soil poor in $\mathrm{Fe}_{\text {ox }}$. The results also suggest that the microbial community may have upregulated its ability to use oxalate in the soils which had received organic acids on a regular basis.

\subsection{Mineral element concentration in plant}

The mineral nutrient concentrations in the chickpea aerial biomass and root are shown in Table 4. Although nutrient concentrations were above established critical levels (Benton Jones et al., 1991), some data deserve attention. Carbon content in the aerial part was inversely related to root nodulation (Tables 1 and 4), because bacteria in nodules need carbohydrates (and other nutrients) from the host plant. 
Table 2. Root architecture characteristics for chickpea plants grown in two calcareous soils (soil poor in $\mathrm{Fe}_{\text {ox }}$ and soil rich in $\left.\mathrm{Fe}_{o x}\right)$ amended without $(-\mathrm{P})$ or with $\mathrm{P}(+\mathrm{P})$ and $\mathrm{P}+$ organic acids $(+\mathrm{P}+\mathrm{OA})$. Values represent mean \pm standard error $(n=5)$. Letters $a, b$ and $c$ denote significant differences between treatments at the $p<0.05$ level. $\mathrm{Fe}_{\mathrm{ox}}$ : Acid oxalate extractable Fe.

\begin{tabular}{|c|c|c|c|c|c|}
\hline Treatment & $\begin{array}{l}\text { Diameter } \\
\mathrm{mm}\end{array}$ & $\begin{array}{l}\text { Total Length } \\
\text { m plant }^{-1}\end{array}$ & $\begin{array}{l}\text { Surface area } \\
\mathrm{cm}^{2} \text { plant }^{-1}\end{array}$ & $\begin{array}{l}\text { Root volume } \\
\mathrm{cm}^{3} \text { plant }^{-1}\end{array}$ & $\begin{array}{l}\text { Tips } \\
\text { No. plant }{ }^{-1}\end{array}$ \\
\hline & Soil Poor in $\mathrm{Fe}_{\mathrm{ox}}$ & & & & \\
\hline$-\mathrm{P}$ & $0.83 \pm 0.02$ & $3.48 \pm 0.16 \mathrm{a}$ & $91 \pm 5 \mathrm{a}$ & $1.91 \pm 0.01 \mathrm{a}$ & $166 \pm 8 \mathrm{a}$ \\
\hline$+\mathrm{P}$ & $0.85 \pm 0.04$ & $2.72 \pm 0.18 b$ & $72 \pm 4 b$ & $1.53 \pm 0.01 \mathrm{~b}$ & $136 \pm 24 a b$ \\
\hline$+\mathrm{P}+\mathrm{OA}$ & $0.91 \pm 0.02$ & $1.84 \pm 0.19 \mathrm{c}$ & $53 \pm 5 \mathrm{c}$ & $1.20 \pm 0.01 \mathrm{~b}$ & $85 \pm 8 b$ \\
\hline \multirow[t]{2}{*}{$P$-value } & 0.146 & $<0.001$ & $<0.001$ & 0.005 & 0.012 \\
\hline & Soil Rich in $\mathrm{Fe}_{o x}$ & & & & \\
\hline$-\mathrm{P}$ & $0.80 \pm 0.02 \mathrm{a}$ & $2.47 \pm 0.18 \mathrm{a}$ & $68 \pm 3$ & $1.36 \pm 0.07$ & $234 \pm 46$ \\
\hline$+\mathrm{P}$ & $0.84 \pm 0.03 \mathrm{ab}$ & $2.37 \pm 0.15 \mathrm{ab}$ & $62 \pm 3$ & $1.31 \pm 0.05$ & $207 \pm 63$ \\
\hline$+\mathrm{P}+\mathrm{OA}$ & $0.89 \pm 0.02 b$ & $1.91 \pm 0.18 \mathrm{~b}$ & $53 \pm 5$ & $1.19 \pm 0.11$ & $166 \pm 22$ \\
\hline$P$-value & 0.040 & 0.015 & 0.051 & 0.344 & 0.594 \\
\hline
\end{tabular}

Table 3. Composition of soil solution obtained from the rhizosphere of chickpea plants grown in two calcareous soils (soil poor in $\mathrm{Fe}_{\mathrm{ox}}$ and soil rich in $\mathrm{Fe}_{\mathrm{ox}}$ ) amended without $(-\mathrm{P})$ or with $\mathrm{P}(+\mathrm{P})$ and $\mathrm{P}+$ organic acids $(+\mathrm{P}+\mathrm{OA})$. Values represent mean \pm standard error $(n=5)$. Letters $a, b$ and $c$ denote significant differences between treatments at the $p<0.05$ level. $\mathrm{Fe}_{\mathrm{ox}}$ : Acid oxalate extractable Fe.

\begin{tabular}{llll}
\hline Treatment & $\mathrm{P}$ & $\mathrm{Fe}$ \\
& $\mathrm{mg} \mathrm{L}^{-1}$ & \\
\hline & Soil Poor in $\mathrm{Fe}_{\mathrm{ox}}$ \\
$-\mathrm{P}$ & $0.7 \pm 0.1 \mathrm{~b}$ & $12.2 \pm 12.2 \mathrm{~b}$ & $7.65 \pm 0.02 \mathrm{~b}$ \\
$+\mathrm{P}$ & $24.9 \pm 1.2 \mathrm{a}$ & $42.8 \pm 18.3 \mathrm{~b}$ & $7.62 \pm 0.02 \mathrm{~b}$ \\
$+\mathrm{P}+\mathrm{OA}$ & $23.6 \pm 2.8 \mathrm{a}$ & $295.6 \pm 112.1 \mathrm{a}$ & $7.97 \pm 0.03 \mathrm{a}$ \\
$P$-value & $<0.001$ & 0.004 & $<0.001$ \\
& & & \\
& Soil Rich in $\mathrm{Fe}_{\mathrm{ox}}$ & \\
$-\mathrm{P}$ & $0.3 \pm 0.1 \mathrm{~b}$ & $79.5 \pm 37.0 \mathrm{~b}$ & $7.75 \pm 0.01 \mathrm{~b}$ \\
$+\mathrm{P}$ & $21.7 \pm 0.3 \mathrm{a}$ & $30.6 \pm 30.6 \mathrm{~b}$ & $7.70 \pm 0.01 \mathrm{~b}$ \\
$+\mathrm{P}+\mathrm{OA}$ & $22.2 \pm 1.9 \mathrm{a}$ & $193.7 \pm 36.8 \mathrm{a}$ & $8.00 \pm 0.04 \mathrm{a}$ \\
$P$-value & $<0.001$ & 0.016 & $<0.001$ \\
\hline
\end{tabular}



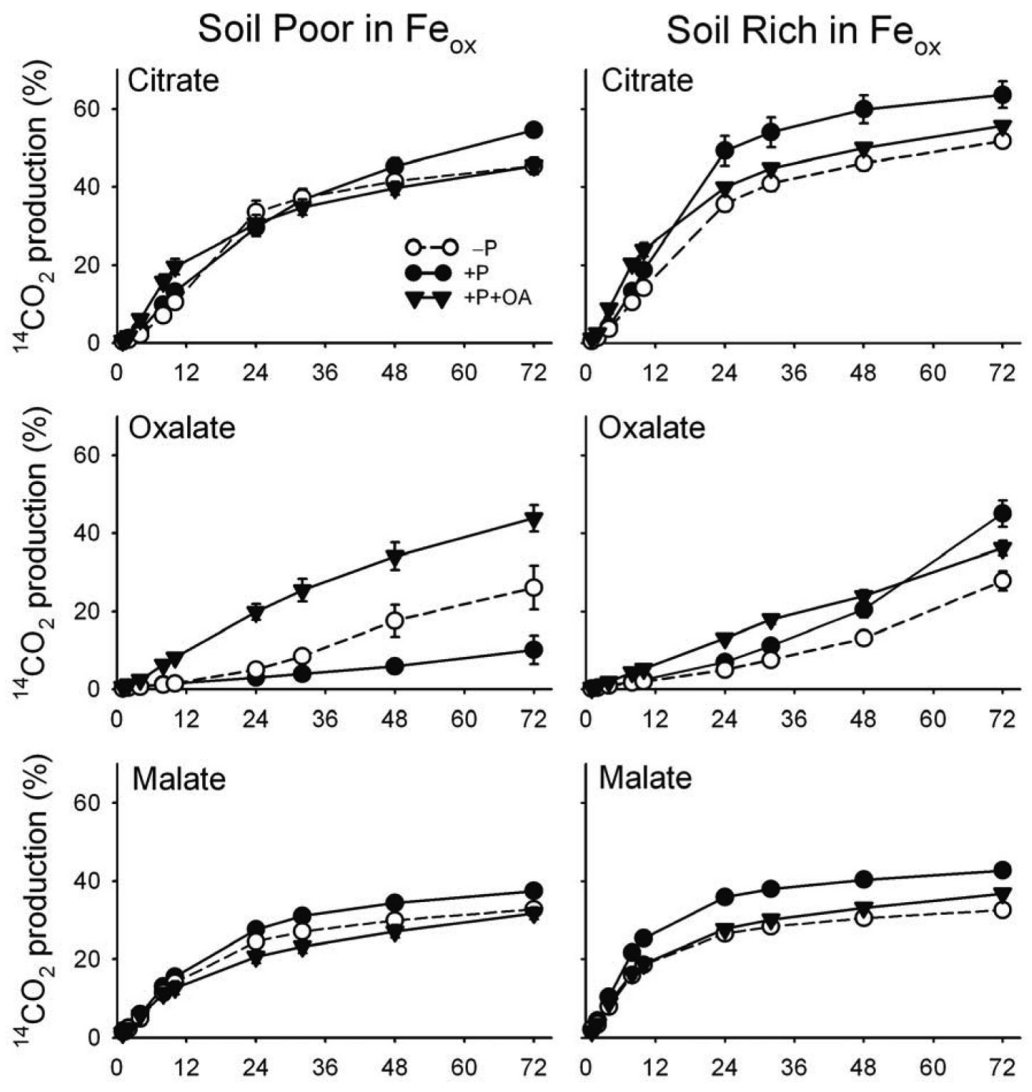

Figure 3. Time course of microbial ${ }^{14} \mathrm{CO}_{2}$ production (\% of total organic acid applied) after the addition of ${ }^{14} \mathrm{C}$-labeled citric, oxalic or malic acid to two calcareous soils (soil poor in $\mathrm{Fe}_{\mathrm{ox}}$ and soil rich in $\mathrm{Fe}_{\mathrm{ox}}$ ) previously treated without $\mathrm{P}(-\mathrm{P})$, with $\mathrm{P}(+\mathrm{P})$ or with $\mathrm{P}+$ organic acids $(+\mathrm{P}+\mathrm{OA})$. Values represent mean \pm standard error $(n$ $=5) . \mathrm{Fe}_{\mathrm{ox}}$ : Acid oxalate extractable Fe.

Control plants $(-\mathrm{P})$ followed by those treated with phosphorus $(+\mathrm{P})$ and then by those treated with organic acids $(+\mathrm{P}+\mathrm{OA})$ had the highest biomass $\mathrm{N}$ concentration despite having less nodulation (Table 1 and 4). Wang et al. (2009) found that organic acids (oxalic, citric and malic) had an inhibitory effect on root nitrogen accumulation, nodulation and nitrogen fixation of soybean grown in sand culture under phosphorus deficient conditions. The conditions in our experiment in which plants were watered with modified Hoagland solution rich in $\mathrm{N}$ would, however, be expected to have a greater regulatory effect on $\mathrm{N}$ fixation.

Plants grown on soil poor in $\mathrm{Fe}_{\mathrm{ox}}$ treated with organic acid $(+\mathrm{P}+\mathrm{OA})$ increased their aerial $\mathrm{P}$ concentration (Table 4). The same effect was observed for roots of plants grown on treated $\mathrm{P}$ soils $(+\mathrm{P})$ and treated with organic acids $(+\mathrm{P}+\mathrm{OA})$ for both soils (data not shown). 
Table 4. Nutrient concentrations in aerial part of chickpea grown in two calcareous soils (soil poor in $\mathrm{Fe}_{\mathrm{ox}}$ and soil rich in $\left.\mathrm{Fe}_{\text {ox }}\right)$ amended without $(-\mathrm{P})$ or with $\mathrm{P}(+\mathrm{P})$ and $\mathrm{P}+$ organic acids $(+\mathrm{P}+\mathrm{OA})$. Values represent mean \pm standard error $(n=5)$. Letters $a, b$ and $c$ denote significant differences between treatments at the $p<0.05$ level. $\mathrm{Fe}_{\text {ox }}:$ Acid oxalate extractable Fe.

\begin{tabular}{|c|c|c|c|c|c|c|c|c|c|}
\hline Treatment & $\begin{array}{l}\mathrm{C} \\
\mathrm{g} \mathrm{kg}^{-1}\end{array}$ & $\mathrm{~N}$ & $\mathrm{P}$ & $\mathrm{K}$ & $\mathrm{Ca}$ & $\mathrm{Mg}$ & $\begin{array}{l}\mathrm{Fe} \\
\mathrm{mg} \mathrm{kg}^{-1}\end{array}$ & Mn & $\mathrm{Cu}$ \\
\hline $\begin{array}{l}-\mathrm{P} \\
+\mathrm{P} \\
+\mathrm{P}+\mathrm{OA}\end{array}$ & $\begin{array}{l}\text { Soil Poor in F } \\
443.5 \pm 1.7 \mathrm{a} \\
417.1 \pm 1.9 \mathrm{~b} \\
421.2 \pm 2.3 \mathrm{c}\end{array}$ & $\begin{array}{l}\mathrm{e}_{\mathrm{ox}} \\
45.8 \pm 1.3 \mathrm{a} \\
35.1 \pm 0.9 \mathrm{~b} \\
27.3 \pm 0.9 \mathrm{c}\end{array}$ & $\begin{array}{l}1.52 \pm 0.05 \mathrm{~b} \\
1.62 \pm 0.05 \mathrm{~b} \\
2.07 \pm 0.17 \mathrm{a}\end{array}$ & $\begin{array}{l}16.4 \pm 3.0 \mathrm{~b} \\
30.6 \pm 2.4 \mathrm{a} \\
28.0 \pm 6.6 \mathrm{ab}\end{array}$ & $\begin{array}{l}17.8 \pm 0.8 b \\
20.4 \pm 0.4 a \\
15.6 \pm 0.4 c\end{array}$ & $\begin{array}{l}1.2 \pm 0.1 \mathrm{~b} \\
1.6 \pm 0.1 \mathrm{a} \\
0.9 \pm 0.0 \mathrm{c}\end{array}$ & $\begin{array}{l}67 \pm 11 b \\
64 \pm 7 b \\
142 \pm 32 a\end{array}$ & $\begin{array}{l}20 \pm 3 b \\
41 \pm 3 a \\
25 \pm 2 b\end{array}$ & $\begin{array}{l}11 \pm 0 \mathrm{a} \\
9 \pm 0 \mathrm{~b} \\
11 \pm 1 \mathrm{a}\end{array}$ \\
\hline$P$-value & $<0.001$ & $<0.001$ & 0.004 & 0.039 & $<0.001$ & $<0.001$ & 0.018 & $<0.001$ & 0.015 \\
\hline $\begin{array}{l}-\mathrm{P} \\
+\mathrm{P} \\
+\mathrm{P}+\mathrm{OA}\end{array}$ & $\begin{array}{l}\text { Soil Rich in F } \\
440.9 \pm 0.8 \text { a } \\
424.1 \pm 1.5 \mathrm{~b} \\
423.9 \pm 1.4 \mathrm{~b}\end{array}$ & $\begin{array}{l}\mathrm{e}_{\mathrm{ox}} \\
46.4 \pm 1.3 \mathrm{a} \\
40.5 \pm 1.0 \mathrm{~b} \\
32.6 \pm 1.4 \mathrm{c}\end{array}$ & $\begin{array}{l}1.57 \pm 0.10 \\
1.43 \pm 0.09 \\
1.88 \pm 0.27\end{array}$ & $\begin{array}{l}21.4 \pm 1.6 \\
25.3 \pm 1.6 \\
28.8 \pm 8.6\end{array}$ & $\begin{array}{l}16.5 \pm 0.3 \mathrm{~b} \\
19.2 \pm 0.3 \mathrm{a} \\
16.5 \pm 0.2 \mathrm{~b}\end{array}$ & $\begin{array}{l}1.7 \pm 0.0 \mathrm{~b} \\
2.2 \pm 0.0 \mathrm{a} \\
1.3 \pm 0.1 \mathrm{c}\end{array}$ & $\begin{array}{l}76 \pm 4 \\
90 \pm 7 \\
72 \pm 16\end{array}$ & $\begin{array}{l}26 \pm 1 b \\
49 \pm 5 a \\
47 \pm 7 a\end{array}$ & $\begin{array}{l}11 \pm 0 \mathrm{a} \\
9 \pm 0 \mathrm{~b} \\
11 \pm 1 \mathrm{a}\end{array}$ \\
\hline$P$-value & $<0.001$ & $<0.001$ & 0.226 & 0.601 & $<0.001$ & $<0.001$ & 0.432 & 0.011 & 0.032 \\
\hline
\end{tabular}

An increasing effect in $\mathrm{K}$ concentration was observed in plants grown on both soils (especially in root, not shown) when organic acids were added $(+\mathrm{P}+\mathrm{OA}$ treatment). It could be because an excessive positive charge is produced by $\mathrm{H}^{+}$from organic acids out of the root cells, decreasing the $\mathrm{H}^{+}$excretion by the roots that uptake $\mathrm{K}^{+}$in order to reduce the positive charge, increasing slightly and significantly the $\mathrm{pH}$ of the rhizosphere in both soils (Table 3).

Calcium concentration decreased for plants treated with organic acid $(+\mathrm{P}+\mathrm{OA})$ possibly due to the formation of $\mathrm{Ca}$-oxalate precipitates reducing the bioavailability of $\mathrm{Ca}$.

\section{Conclusions}

Non-crystalline $\mathrm{Fe}$ oxides have an important role in the availability of $\mathrm{Fe}$ for plants. Therefore, leaf chlorophyll content was higher in chickpea grown on the soil rich than on the soil poor in $\mathrm{Fe}_{\mathrm{ox}}$. The negative effect of high $\mathrm{P}$ fertilization on $\mathrm{Fe}$ chlorosis in chickpea was partially alleviated (increased SPAD value and leaf chlorophyll content, and reduced root ferric reductase activity) with the addition of organic acids to the soil, especially for the soil with the lower
$\mathrm{Fe}_{\text {ox }}$ content. However, the Fe chlorosis symptoms were more severe in chickpea growing on soils treated with organic acids than in control plants which received no P. The increase in Fe availability ( $\mathrm{Fe}$ in soil solution) as a result of organic acids addition could indirectly inhibit the root response mechanisms (i.e. increase of root diameter in comparison with control plants), reducing the production of fine roots needed to explore the soil for nutrient acquisition.

\section{Acknowledgements}

This work was funded by the Spanish Ministries of Science and Innovation (Project AGL200805053-C02-02), Education, Culture and Sport (University Teacher Training Scholarship AP200804716), the European Regional Development Fund and the UK Natural Environment Research Council.

\section{References}

Adrian, W.J. 1973. A comparison of a wet pressure digestion method with other commonly used wet and dry-ashing methods. Analyst. 98, 213-216. 
Balal, R., Shahid, M.A., Lidon, V., Garcia, A.L., Abbas, T., Garcia-Sanchez, F., Ghazanfer, U. 2011. Effects of phosphorus fertilization on growth, leaf mineral concentration and xylem-phloem nutrient mobility in two rootstocks of prunus (Prunus persica $x$ Prunus amygdalus and Prunus insititia) in the Mediterranean. Aust. J. Crop. Sci. 5, 15421549 .

Benton Jones, J., Wolf, B., Mills, H.A. 1991. Plant analysis handbook. A practical sampling, preparation, analysis, and interpretation guide. Micro-Macro Publishing, Georgia. 213 p.

Bigham, J.M., Fitzpatrick, R.W., Schulze, D.G. 2002. Iron oxides. In: J.B. Dixon, D.G. Schulze DG (eds). Soil Mineralogy with Environmental Applications. SSSA Book Series 7. Madison, pp: 323-366.

Brown, J.C., Olsen, R.A. 1980. Factors related to iron uptake by dicotyledonous and monocotyledonous plants III. Competition between root and external factors for Fe. J. Plant Nutr. 2, 661-682.

Cassman, K.G., Whitney, A.S., Stockinger, K.R. 1980. Root growth and dry matter distribution of soybean as affected by phosphorus stress, nodulation and nitrogen source. Crop Sci. 20, 238-244.

Cornell, R.M., Schwertmann, U. 2003. The iron oxides. John Wiley \& Sons, Weinheim, 664 p.

de Kock, P.C., Hall, A. 1955. The phosphorus-iron relationship in genetical chlorosis. Plant Physiol. 30, 293-295.

Díaz, I., del Campillo, M.C., Cantos, M., Torrent, J. 2009. Iron deficiency symptoms in grapevine as affected by the iron oxide and carbonate contents of model substrates. Plant Soil. 322, 293-302.

Drouineau, G. 1942. Dosage rapide du calcaireactif des sols. Nouvellesdonnéessur la repartition et la nature des fractions calcaires. Annal. Agron. 12, $441-450$.
Ellsworth, J.W., Jolley, V.D., Nuland, D.S., Blaylock, A.D. 1997. Screening for resistance to iron deficiency chlorosis in dry bean using reduction capacity. J. Plant Nutr. 20, 1489-1502.

Jones D.L. 1998. Organic acids in the rhizosphere: a critical review. Plant Soil. 205, 25-44.

Kovanci, I., Hakerlerler, H., Höfner, W. 1978. Ursachen der Chlorosen an Mandarinen (Citrus recitulata blanco): der äigaäiischen Region. Plant Soil. 50, 193-205.

Ladouceur, A.S., Tozawa, S., Alam, S., Kamei, S., Kawai, S. 2006. Effect of low phosphorus and iron-deficient conditions on phytosiderophore release and mineral nutrition in barley. Soil Sci. Plant Nutr. 52, 203-210.

Marschner, H., Schropp, A. 1977. Vergleichen de Untersuchungenüber die Empfindlichkeitvon 6 Unterlagssorten der Weinrebe gegenüber phosphat induziertem Zn-Mangel. Vitis. 16, 79-88.

Mehra, O.P., Jackson, M.L. 1960. Iron oxide removal from soil and clays by a dithionite-citrate system buffered with sodium bicarbonate. Clay Clay Miner. 7, 317-327.

Mengel, K., Breiniger, M.T., Bülb, W. 1984. Bicarbonate, the most important factor inducing chlorosis in vine grapes on calcareous soils. Plant Soil. 81, 333-344.

Mengel, K., Scherer, H.W., Malissiovas, N. 1979. Die Chloroseaus der Sicht der Bodenchemie und Rebenernährung. Mitt. Klosterneuburg. 29, 151-156.

Mullner, L. $\quad 1970 . \quad$ Ergebnisseeines. Chloroseforschungsprojektes.Mitt. Klosterneuburg. 29, 141-150.

Murphy, J., Riley, J.P. 1962. A modified single solution method for the determination of phosphate in natural waters. Anal. Chim. Acta. 27, 31-36. 
Olsen, R.A., Cole, V., Watanabe, F.S., Dean, L.A. 1954. Estimation of available phosphorus in soils by extraction with sodium bicarbonate. Washington DC. USDA Cir. 939, 1-19.

Reyes, I., Torrent, J. 1997. Citrate-ascorbate as a highly selective extractant for poorly crystalline iron oxides. Soil Sci. Soc. Am. J. 61, 1647-1654.

Romera, F.J., Alcántara, E., de la Guardia, M.D. 1991. Characterization of the tolerance to iron chlorosis in different peach rootstocks grown in nutrient solution. II. Iron stress response mechanisms. Plant Soil. 130, 120-124.

Ryan, P.R., Delhaize, E., Jones, D.L. 2001. Function and mechanism of organic anion exudation from plant roots. Annu. Rev. Plant Phyisiol. Plant Mol. Biol. 52, 527-560.

Samar, S.M., Shahabian, M., Fallahi, E., Davoodi, M.H., Bagheri, Y.R., Noorgholipoor, F. 2007. Iron deficiency of apple tree as affected by increasing soil available phosphorus. J. Plant Nutr. 30, 1-7.
Sánchez-Rodríguez, A.R., del Campillo, M.C., Torrent, J. 2013. Phosphate aggravates iron chlorosis in sensitive plants grown on model calcium carbonate-iron oxide systems. Plant Soil DOI: 10.1007/s11104-013-1785-y

Schwertmann, U. 1964. Differenzierung der Eisenoxide des BodensdurchExtraktion mit Ammoniumoxalat-Lösung. Z. Pflanzenähr. Bodenk. 105, 194-202.

Ström, L., Owen, A.G., Godbold, D.L., Jones, D.L. 2002. Organic acid mediated mobilization in the rhizosphere and uptake by maize roots. Soil Biol. Biochem. 34, 703-710.

Van Wesemael, J.C. 1955. De bepaling van hetcalciumcarbo-naatgehalte van gronden. Chem. Weekbl. 51, 35-36.

Wang, S.Q., Han, X.Z., Quiao, Y.F., Yan, J., Li, X.H. 2009. Effects of low molecular organic acids on nitrogen accumulation, nodulation, and nitrogen fixation of soybean (Glycine max L.) under phosphorus deficiency stress. J. Appl. Ecol. 20, 1079-1084. 